\title{
Obtaining a new source of biofuel from olive mill wastewater using solar energy
}

\author{
S. Gharaibeh ${ }^{1}$ Aiman Q. Jaradat ${ }^{2}$ \\ ${ }^{1}$ Department of Earth and Environmental Sciences, Yarmouk University, Irbid, Jordan \\ ${ }^{2}$ Department of Civil Engineering, Yarmouk University, Irbid, Jordan
}

Received: 17 November 2015/Revised: 5 January 2016/Accepted: 27 October 2016/Published online: 9 November 2016

(c) Joint Center on Global Change and Earth System Science of the University of Maryland and Beijing Normal University and Springer-Verlag Berlin Heidelberg 2016

\begin{abstract}
This work is aimed to evaluate the applicability of solid portion of olive mill wastewater (OMW) for its utility as a renewable biofuel. A solar still unit was used to separate the solid residual from the liquid part of OMW. Three triplicate samples of solid residue were collected and tested for their calorific value, proximate analysis, and elemental analysis. The average calorific values obtained based on oxygen bomb calorimeter were $24 \pm 0.65 \mathrm{~kJ} / \mathrm{g}$ which agreed well with that obtained from elemental analysis $(23 \pm 1.3 \mathrm{~kJ} / \mathrm{g})$. This value is higher than that of refuse-derived fuel and lower than that of oil or natural gas but close to that of coal. Results of proximate analysis indicate a high combustible portion (83\%) of OMW-Biofuel. The total amount of energy that can be produced from OMW-Biofuel in Jordan, expressed in terms of oil equivalent, accounts for $<1.0 \%$ of the total imported oil by Jordan in 2014 and, if utilized, would result in annual savings of about US\$ 17 million. These results suggest that the OMW-Biofuel can be applicable as a potential fuel.
\end{abstract}

Keywords Biofuel · Olive mill wastewater - Solar still · Calorific value . Treatment

\section{Introduction}

Worldwide, notably in the Mediterranean and Middle East countries, the olive oil extraction industry is growing progressively and continuously. In these countries, the high quantities of produced olive oil generate large volumes of

S. Gharaibeh

samehgh@yu.edu.jo olive mill wastewater (OMW) (International Olive Oil Council [IOOC] 2005; Mili 2004). The OMW is a dark, brown, acidic liquid with intense smell, phytotoxic, and composed of vegetation water from the olives and water from the extraction process (Scioli and Vollaro 1997). The OMW is characterized by a very high concentration of chemical oxygen demand (COD) and biological oxygen demand (BOD) and containing a very high amount of organics presented in the form of phenols, pectin, and colloids (Potoglou et al. 2004).

However, extensive research has been done to date addressing safe disposal or reasonable treatment of OMW (Borja et al. 1995; Flouri et al. 1996; Gharaibeh et al. 2008; Kavvadias et al. 2010; Saadi et al. 2007; Ubay and Ozturk 1997). The olive oil producing countries still facing stubborn obstacles regarding environmental pollution due to the lack of feasible and economical solutions to deal properly with the discharged OMW (Tomati 2001). Jordan falls into this category facing problems in managing the large volumes of OMW discharged from numerous olive mills distributed all over the country.

Currently, there are more than 110 three-phase olive mills with 140 production lines distributed throughout Jordan discharging more than $400,000 \mathrm{~m}^{3}$ yearly of OMW (Ministry of environment, Personal communications 2014). Considering the increase in cultivated land area with olive oil trees ( $>17$ million), this quantity of discharged OMW will be increased as well.

Based on modern integrated waste management policy, the concept of "waste" is replaced by a concept of "source" (Tchobanoglous et al. 1993). Thus, the OMW can be viewed as being a "source" rather than being "waste" because it contains various beneficial compounds due to 
the presence of phenols and polyphenols that can be used as therapeutics (D'Annibale et al. 1998; Shadabi et al. 2013) and solid materials (biowaste) that can be used as a new source of biofuel.

Meanwhile, the increase in energy prices and the needs for reducing the consumption of fossil fuels have drawn increasing attention to the development of alternative technologies to produce renewable energy. The need for low-cost energy is most apparent in small countries, particularly the ones that depend solely on imports of petroleum products. Jordan, a small nation with no local energy sources, spends about $17 \%$ of its gross domestic product (GDP) on imported petroleum products. Therefore, providing adequate and clean energy is considered to be one of the main challenges for sustainable development in Jordan and other nonproducing oil countries.

Biomass is a feasible energy source that can reduce dependency on imported oil. Preliminary studies carried out by the National Energy Research Centre of Jordan show that biogas from animal and domestic waste can save up to $4 \%$ of imported oil (Ministry of Energy and Mineral Resources [MEMR] Ministry of Energy and Mineral Resources 2013).

The applicability of different types of biomass as an alternative source of energy has been investigated by many researchers (Abu-Qdais and Abu Qdais 2000; Caputo et al. 2003; Ginkel et al. 2005; Intini et al. 2011; Shin et al. 2004; Traore 1992). For example, the olive mill solid waste, known as pomace, husk, or olive cake, has been studied extensively in the past two decades and is used today as fuel for heating (Tawarah 2014).

The applicability of OMW for energy recovery has been studied to a less extent. Thermal processes were found to be the main option for the treatment of OMW. However, due to the high water content of OMW thermal treatment is not economically viable although combustion of concentrated OMW with olive mill waste has been already studied (Chouchene et al. 2012; Caputo et al. 2003; Miranda et al. 2008; Vitolo et al. 1999). Miranda et al. (2008), for example, studied the thermal behavior of concentrated olive mill wastewater (COMWW) and other olive residues. They found that the high moisture (73\%) and ash contents in COMWW make it inviable to keep the combustion process. The present research has been conducted to examine the feasibility of separating OMW into solid materials that may be used directly as a renewable new source of biofuel and condensed water containing possible beneficial natural compounds, thus reducing the volume of OMW in an environmentally acceptable manner. Detailed evaluation of the condensed water for possible beneficial products will be provided via a separate research article.

\section{Materials and methods}

This work was conducted on a pilot-scale level using fiberglass solar still units to separate OMW into solid materials and condensed water. Every solar still unit consists mainly of two parts, a basin to contain the OMW and a 2-mm-thick transparent glass cover with an inclination of $21^{\circ}$ to serve as condenser. Edges of the glass were sealed so that the entire still becomes air tight. Figure 1 shows a diagram of the solar still with its dimensions.

Samples of OMW, discharged from three-phase extraction systems, were collected from Saadon, Yarmouk, and Shula olive mills located in Irbid province north of Jordan. The concentrations of the solid residuals (the potential OMW-Biofuel) in the three OMW sources were evaluated by taking three replicate samples $(1 \mathrm{~L}$ each) of OMW from each OMW source. These samples were placed in shallow vast plastic containers and dried using an electric oven at $55{ }^{\circ} \mathrm{C}$. This temperature was chosen because the highest temperature achieved in the solar still was less than $60{ }^{\circ} \mathrm{C}$. The potential OMW-Biofuel were weighed and recorded.

A solar still experiment has been conducted for 6 months, starting on November 5, 2014. Ambient air temperature, air and OMW temperatures inside the solar still, and depth reduction were recorded daily. Three solar still units were filled up to a depth of $14 \mathrm{~cm}$ (equivalent to 65.5 L) of OMW, collected from the three different local olive mills, placed outdoor, and faced south to receive maximum solar radiation. Solar radiation is trapped within the basin and the cover resulting in an increase in the temperature inside the solar still (greenhouse effect). Consequently, the rate of distillation (vaporization) is accelerated.

The condensed water (condensate) produced on the inner glass cover surface (condenser) was transferred through the trough into a storage container. The remaining part, after removing the water via condensation, represents the solid residual that has been evaluated for its utility as a potential OMW-Biofuel. The solid residuals were collected

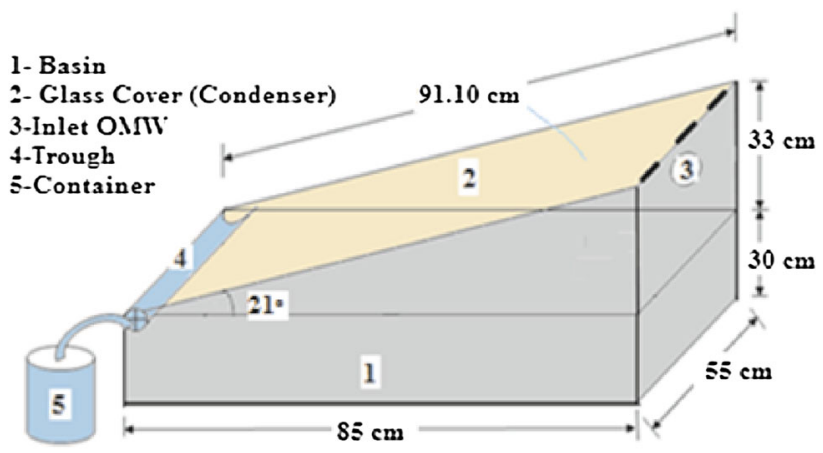

Fig. 1 Solar still unit 
from the basins (almost odor free), dried outdoor by winds and sun rays for few days for extra removal of moisture and finally evaluated as a potential OMW-Biofuel.

Triplicate samples of the potential OMW-Biofuel from each solar still were collected and tested for their calorific value using an oxygen bomb calorimeter according to ASTM E-711 standard test method (ASTM 2004). The moisture content, volatile matter, fixed carbon, and ash content have been tested as well. These tests represent the proximate analysis which is usually used as an indicator for capability of organic solid materials as a fuel (Singer 1981). Moisture content was determined by measuring the weight loss after the samples were dried at $105{ }^{\circ} \mathrm{C}$ overnight according to ASTM E1756-08 standard test method (ASTM 2008). The triplicate samples of the potential OMW-Biofuel used in the moisture content determination were weighed and placed in muffle furnace (Carbolite, Sheffield, England) overnight at $550{ }^{\circ} \mathrm{C}$ for determining the ash content according to ASTM E1755-01 standard test method (ASTM 2007). The volatile matter content was obtained by determining the weight loss after combustion of the dried samples at $950{ }^{\circ} \mathrm{C}$ according to ASTM E87282 standard test method (ASTM 2013). Fixed carbon was then calculated by subtracting the sum of ash, volatile matter, and moisture content from $100 \%$.

Additionally, elemental analysis (known as ultimate analysis for fuel) including $\mathrm{C}, \mathrm{H}, \mathrm{N}, \mathrm{O}, \mathrm{S}$, and ash content was conducted to predict possible gas releases resulting from combustion of the OMW-Biofuel and to verify the results of calorific value obtained by oxygen bomb calorimeter (Shukla 1997). The contents of C, H, and N were tested using Euro Vector 3000 Elemental Analyzer and that of $\mathrm{S}$ was tested using Leco S-144DR Sulfur Analyzer. The $\mathrm{O}_{2}$ content was obtained by subtracting from $100 \%$ the sum of $\mathrm{C}, \mathrm{H}, \mathrm{N}, \mathrm{S}$, and ash contents in percentage. The net calorific value $(\mathrm{NCV})(\mathrm{kJ} / \mathrm{g})$ and gross calorific value $(\mathrm{GCV})(\mathrm{kJ} / \mathrm{g})$ of OMW-Biofuel were calculated from elemental analysis using Eqs. 1 and 2 (Morvay and Gvozdenac 2008)

$\mathrm{NCV}=33.9 \mathrm{C}+117\left(\mathrm{H}-\frac{\mathrm{O}}{8}\right)+10.5 \mathrm{~S}-2.5 \mathrm{~W}$

$\mathrm{GCV}=\mathrm{NCV}+2.5(9 \mathrm{H}+\mathrm{W})$

where $\mathrm{C}, \mathrm{H}, \mathrm{O}, \mathrm{S}$, and $\mathrm{W}$ denote mass fraction (\%) of carbon, hydrogen, oxygen, sulfur, and water contents, respectively.

The concentrations of $\mathrm{Fe}, \mathrm{Mg}, \mathrm{Al}, \mathrm{Si}, \mathrm{Zn}, \mathrm{Cu}, \mathrm{Cr}, \mathrm{Ni}$, $\mathrm{Cd}, \mathrm{Sn}, \mathrm{Co}$, and $\mathrm{Pb}$ in three composite samples from the different OMW-Biofuel sources and their bottom ash were determined in the liquid phase after digestion with $35.4 \%$ hydrochloric acids and $40 \%$ hydrofluoric acids using an atomic absorption spectrophotometer (AAS) (Thermo Electron Solar S4 AA Spectrometer).

\section{Results and discussion}

The recorded daily average ambient temperatures varied from a minimum of $8^{\circ} \mathrm{C}$ on January, 2015 to a maximum of $33{ }^{\circ} \mathrm{C}$ on April, 2015. The air and OMW temperatures inside the solar still did not exceed 45 and $55^{\circ} \mathrm{C}$, respectively, due to the accumulation of condensate on the inner glass cover surface (condenser) and vapors, thus reducing the amounts of solar radiation that penetrate the glass cover into the solar still. The depth of OMW was reduced significantly from $14.0 \mathrm{~cm}$ (corresponding to $65.45 \mathrm{~L}$ ) at the beginning of the experiment to $1.5 \mathrm{~cm}$ (corresponding to $28 \mathrm{~L}$ ) at the end leaving only a solid residual materials with moisture content of about $20 \%$ which is lower than that obtained by other researchers (Miranda et al. 2008).

The average results of the total solid concentration in OMW (the potential OMW-Biofuel) from three different sources with their average calorific values are presented in Table 1. Total solids concentration varies from 90 to $110 \mathrm{mg} / \mathrm{L}$ with an average value of $103 \mathrm{mg} / \mathrm{L}$. This variation is attributed mainly to the separating efficiency of OMW from the olive oil. Higher separation efficiency generates larger amounts of OMW-Biofuel.

The average calorific values (energy density) obtained were $24.0 \mathrm{~kJ} / \mathrm{g}$. This value is higher than that of Eco-fuel or refuse-derived fuel (RDF) $(14 \mathrm{~kJ} / \mathrm{g})$ (Channiwala and Parikh 2001) and lower than that of oil or natural gas $(43.0 \mathrm{~kJ} / \mathrm{g}$ ) but close to that of coal $(15-27 \mathrm{~kJ} / \mathrm{g}$ ) (World Nuclear Association [WNA] 2010), suggesting that the OMW-Biofuel can be used as a new source of biofuel.

The total amounts of OMW-Biofuel that can be produced from OMW in Jordan are about 41,200 ton yearly (based on $400,000 \mathrm{~m}^{3}$ of OMW discharged yearly and $103 \mathrm{~g} / \mathrm{L}$ of total solids concentration). From the calculated average energy content $(24.0 \mathrm{~kJ} / \mathrm{g}=5736 \mathrm{kcal} / \mathrm{kg})$, this amount of OMW-Biofuel will yield about $2.36 \times 10^{11}$ $\mathrm{kcal} / \mathrm{yr}$ of energy which is equivalent to about $2.36 \times 10^{4}$ tons/yr of fuel oil (based on an oil equivalent of $10,000 \mathrm{kcal} / \mathrm{kg}$ ) (Harker and Backhurst, 1981). This amount of energy that can be produced from OMW-Biofuel in Jordan, expressed in terms of oil equivalent, accounts for $<1.0 \%$ of the total imported oil by Jordan in 2014 $\left(7.1 \times 10^{6}\right.$ tons/year) and, if utilized, would result in annual savings of about US\$ 17 million based on oil prices in 2014. Moreover, converting the energy content of OMW-Biofuel in Jordan to electric energy will yield about $275 \mathrm{GWh}$ /year. This energy is sufficient to provide electric power for approximately 125,000 person/day (based on the 
Table 1 Concentrations of the potential OMW-Biofuel sources and their caloric values

\begin{tabular}{llcl}
\hline Olive mill & No. of samples & OMW-Biofuel $(\mathrm{g} / \mathrm{L})$ & Calorific value $(\mathrm{kJ} / \mathrm{g})$ \\
\hline Saadon & 3 & $110 \pm 7.5$ & $24.7 \pm 2.2$ \\
Yarmouk & 3 & $109 \pm 8.1$ & $23.9 \pm 2.5$ \\
Shula & 3 & $90 \pm 6.4$ & $23.4 \pm 2.4$ \\
Average & - & $103 \pm 11.2$ & $24.0 \pm 0.65$ \\
\hline
\end{tabular}

annual average value of $2225 \mathrm{Kwh} / \mathrm{capita}$ of electric power consumption in Jordan).

Table 2 shows the average results of the proximate analyses for the three different potential OMW-Biofuel sources. The average values of moisture and ash contents were low (9.7 and 3.8\%, respectively) and that of volatile matter and fixed carbon were high (76.1 and 7.9\%, respectively). Moisture and ash content (13.5\%) represent the noncombustible portion of solid residual. Both are undesirable as they add weight to the fuel without adding to the heating value. The volatile matter and the fixed carbon $(84.0 \%)$ are the preferred indicators of the combustion capability of a solid material/fuel.

The results of elemental analysis for different sources of OMW-Biofuel are presented in Table 3. The results obtained showed low concentration of $\mathrm{N}$ and $\mathrm{S}$ (1.77 and $0.26 \%$, respectively) but high concentration of $\mathrm{C}(56 \%)$. The quantity of bottom ash that may be generated by the combustion of OMW-Biofuel is about 2719 per year (based on 41,200 ton OMW-Biofuel and 6.6\% bottom ash).

To evaluate the performance of biofuel combustion in plant, it usually refers to the NCV, because the most common boilers do not allow to recover the heat of water condensation (Morvay and Gvozdenac 2008). The calculated NCV based on elemental analysis is $22.9(\mathrm{~kJ} / \mathrm{g})$ and that of GCV is $24.7(\mathrm{~kJ} / \mathrm{g})$ which agreed well with calorific value obtained experimentally by oxygen bomb calorimeter $(24 \mathrm{~kJ} / \mathrm{g})$.

Combustion of biomass can pose air pollution depending on the biomass source, type of power plant and types of pollution controls installed at the plant, but the most common pollutants include $\mathrm{CO}_{\mathrm{X}}, \mathrm{NO}_{\mathrm{X}}, \mathrm{SO}_{\mathrm{X}}$, and particulate matter (PM).The results of ultimate analysis showed low content of $\mathrm{N}$ and $\mathrm{S}$ (1.77 and $0.26 \%$, respectively) but high content of C $(56 \%)$ and ash (6.6\%). These results suggest that the main air emissions that would be resulted from burning of OMWBiofuel are $\mathrm{CO}_{2}$ and PM, but these emissions can be significantly reduced with using a control system such as fluidized bed and/or gasification systems. However, compared to coal $(85 \% \mathrm{C})$ and liquid petroleum gas $(82 \% \mathrm{C})$ (Morvay and Gvozdenac 2008), the expected $\mathrm{CO}_{2}$ emissions resulted from combustion of OMW-Biofuel would be lower.

Nevertheless, the utilization of OMW-Biofuel is an environmentally friendly process. The $\mathrm{CO}_{2}$ emission from combustion of the OMW-Biofuel may not be considered as an additional greenhouse gas because its origin is from the troposphere and not from the stored fossil sources.

In addition, the metal concentrations in the OMW-Biofuel samples are relatively low while their concentrations were increased in the bottom ash (Table 4) due to the evaporation of organic matter and other volatiles from the OMW-Biofuel samples during combustion. In general,
Table 2 Proximate analyses of the potential OMW-Biofuel sources

\begin{tabular}{llllll}
\hline Olive mill & No. of samples & Moisture $(\%)$ & Volatile matter $(\%)$ & Ash $(\%)$ & Fixed carbon $(\%)$ \\
\hline Saadon & 3 & $9.1 \pm 0.56$ & $78.38 \pm 1.2$ & $4.1 \pm 0.3$ & $7.8 \pm 0.63$ \\
Yarmouk & 3 & $9.8 \pm 0.61$ & $75.39 \pm 1.6$ & $2.1 \pm 0.2$ & $7.9 \pm 0.54$ \\
Shula & 3 & $10.3 \pm 0.4$ & $74.48 \pm 1.1$ & $5.3 \pm 0.3$ & $7.9 \pm 0.51$ \\
Average & - & 9.7 & 76.1 & 3.8 & 7.9 \\
\hline
\end{tabular}

Table 3 Ultimate analysis of the OMW-Biofuel

\begin{tabular}{llllllll}
\hline Olive Mill & No. of samples & C & H & N & S & O \\
wt $(\%)$ & wt (\%) & wt (\%) & $\begin{array}{l}\text { Ash } \\
\text { wt (\%) }\end{array}$ \\
\hline Saadon & 3 & $56 \pm 2.5$ & $7.3 \pm 0.68$ & $3.3 \pm 0.14$ & $0.3 \pm 0.02$ & $26.6 \pm 2.1$ & $6.4 \pm 0.78$ \\
Yarmouk & 3 & $56.4 \pm 2.1$ & $7.74 \pm 0.74$ & $1.1 \pm 0.07$ & $0.26 \pm 0.01$ & $28.4 \pm 2.6$ & $6.1 \pm 0.65$ \\
Shula & 3 & $53.72 \pm 1.9$ & $6.73 \pm 0.66$ & $1.0 \pm 0.1$ & $0.23 \pm 0.01$ & $30.9 \pm 3.1$ & $7.4 \pm 0.61$ \\
Average & - & 55.41 & 7.25 & 1.77 & 0.26 & 28.6 \\
\hline
\end{tabular}


Table 4 Metal concentrations $(\mathrm{mg} / \mathrm{kg})$ in the OMW-Biofuel and their bottom ash

\begin{tabular}{|c|c|c|c|c|c|c|}
\hline \multirow[t]{2}{*}{ Metals (mg/kg) } & \multicolumn{3}{|c|}{ OMW-Biofuel } & \multicolumn{3}{|c|}{ Bottom ash } \\
\hline & Saadon & Yarmouk & Shula & Saadon & Yarmouk & Shula \\
\hline $\mathrm{Fe}$ & 696 & 254 & 98 & 12,200 & 3800 & 2500 \\
\hline $\mathrm{Mg}$ & 436 & 370 & 691 & 4500 & 36,500 & 81,800 \\
\hline $\mathrm{Al}$ & 396 & 347 & 204 & 2700 & 6400 & 3200 \\
\hline $\mathrm{Si}$ & 1380 & 1070 & 559 & 43,100 & - & - \\
\hline $\mathrm{Zn}$ & 49 & 30 & 22 & 420 & 250 & 260 \\
\hline $\mathrm{Cu}$ & 70 & 45 & 32 & 300 & 200 & 200 \\
\hline $\mathrm{Cr}$ & ND & 7.5 & ND & 60 & 50 & 90 \\
\hline $\mathrm{Ni}$ & 7.4 & 7 & 5.7 & 74 & 60 & 110 \\
\hline $\mathrm{Cd}$ & ND & ND & ND & ND & ND & ND \\
\hline Sn & ND & ND & ND & ND & ND & ND \\
\hline Co & ND & ND & ND & ND & ND & ND \\
\hline $\mathrm{Pb}$ & ND & ND & ND & ND & ND & ND \\
\hline
\end{tabular}

The main air emissions that would be resulted from burning of OMW-Biofuel are $\mathrm{CO}_{\mathrm{x}}$ and $\mathrm{PM}$, but these emissions can be significantly reduced with using a control system such as fluidized bed and/or gasification systems. The $\mathrm{CO}_{2}$ emission from the OMW-Biofuel may not be considered as an additional greenhouse gas because it is a renewable resource and its origin is from the troposphere and not from the stored fossil sources. The ash resulted from burning of OMW-Biofuel may be used as soil conditioner due to the presence of trace elements and the absence of toxic metals.

In general, the results suggest that the OMW-Biofuel can be applicable as a potential fuel. This type of OMW management could represent a fruitful and worth trying solution of OMW disposal in Jordan and may thus pave the way for solving the problems of other olive oil producing countries.

Acknowledgements The authors acknowledge the Scientific Research Support Fund for their financial support, and the Dean of Research and Graduate Studies at Yarmouk University and the managers of the olive mills (Saadon, Yarmouk, and Shula) for their kind cooperation.

\section{References}

duced from OMW using solar distillation technique. The combustible portion of OMW-Biofuel accounts for about $84 \%$ while that of noncombustible portion accounts for about $13 \%$. The average calorific values obtained based on oxygen bomb calorimeter were $24 \mathrm{~kJ} / \mathrm{g}$ which is higher than that of RDF and lower than that of oil or natural gas but close to that of coal.

The total amount of OMW-Biofuel that can be obtained yearly in Jordan from OMW will yield $6.47 \times 108 \mathrm{kcal} /-$ day of energy which, if utilized, would result in annual savings of about US\$17 million. However, detailed economical study is strongly recommended to justify the value of using OMW-Biofuel as a new source of energy.
Abu-Qdais M, Abu Qdais H (2000) Energy content of municipal solid waste in Jordan and its potential utilization. Energy Conserv Manag 41:983-991

ASTM E1755-01 (2007) Standard test method for ash in biomass. ASTM International, West Conshohocken

ASTM E1756-08 (2008) Standard test method for determination of total solids in biomass. ASTM International, West Conshohocken

ASTM E711-87 (2004) Standard test method for gross calorific value of refuse-derived fuel by the bomb calorimeter. ASTM International, West Conshohocken

ASTM E872-82 (2013) Standard test method for volatile matter in the analysis of particulate wood fuels. ASTM International, West Conshohocken 
Borja R, Martin A, Alonso V, Garcia I, Banks CJ (1995) Influence of different aerobic pretreatments on the kinetics of anaerobic digestion of olive mill wastewater. Water Resour 29:489-495

Caputo A, Scacchia F, Pelagagge P (2003) Disposal of byproducts in olive oil industry: waste-to-energy solutions. Appl Therm Eng 23:97-214

Channiwala SA, Parikh PP (2001) A unified correlation for estimating HHV of solid, liquid and gaseous fuels. Fuel 81:1056-1057

Chouchene A, Jeguirim M, Favre-Reguillon A, Trouvé G, Le Buzit G, Khiari B, Zagrouba F (2012) Energetic valorisation of olive mill wastewater impregnated on low cost absorbent: sawdust versus olive solid waste. Energy 39:74-81

D’Annibale A, Crestini C, Vinciguerra V, Giovannozzi SG (1998) The biodegradation of recalcitrant effluents from an olive mill by a white-rot fungus. J Biotechnol 61(3):209-218

Flouri F, Sotirchos D, Ioannidou S, Balis C (1996) Decolourization of olive oil mill liquid wastes by chemical and biological means. Int Biodeterior Biodegrad 38(3-4):189-192

Gharaibeh S, Rababah A, Nishino H (2008) Low cost treatment and disposal of olive mill wastewater. Pollut Solut 9:4-6

Ginkel SV, Oh SE, Logan BE (2005) Biohydrogen production from food processing and domestic wastewaters. Int $\mathrm{J}$ Hydrogen Energy 30:1535-1542

Harker JH, Backhurst JR (1981) Fuel and energy (Energy science and engineering). Academic Press, London

International Olive Oil Council (2005) Retrieved from the internet on April 2015 at: http://www.internationaloliveoil.org/economics3. asp

Intini F, Kühtz S, Rospi G (2011) Energy recovery of the solid waste of the olive oil industries-LCA analysis and carbon footprint assessment. J Sustain Energy Environ 2:157-166

Kavvadias V, Doulaa MK, Komnitsas K, Liakopoulou N (2010) Disposal of olive oil mill wastes in evaporation ponds: effects on soil properties. J Hazard Mater 182:144-155

Mili S (2004) Prospects for olive oil marketing in non-traditional markets. In: Proceedings of the AIEA2 international conference of sustainable development and globalisation of agri-food markets, 23-24, Québec, Canada

Ministry of Energy and Mineral Resources (2013) Annual report. Amman, Jordan. Retrieved from the internet on April 2015 at http://www.memr.gov.jo/LinkClick.aspx?fileticket=B495BBqc Ns4\%3D\&tabid=111
Miranda T, Esteban A, Rojas S, Montero I, Ruiz A (2008) Combustion analysis of different olive residues. Int $\mathrm{J}$ Mol Sci 9:512-525

Morvay Z, Gvozdenac D (2008) Applied industrial energy and environmental management. Wiley, Hoboken

Potoglou D, Kouzeli KA, Haralambopoulos D (2004) Solar distillation of olive mill wastewater. Renew Energy 29:569-579

Saadi I, Laor Y, Raviv M, Medina S (2007) Land spreading of olive mill wastewater: effects on soil microbial activity and potential phytotoxicity. Chemosphere 66:75-83

Scioli C, Vollaro L (1997) The use of Yarrowia lipolytica to reduce pollution in olive mill wastewaters. Water Resour 3:2520-2524

Shadabi S, Ghiasvand AR, Hashemi P (2013) Selective separation of essential phenolic compounds from olive oil mill wastewater using a bulk liquid membrane. Chem Pap 67:730-736

Shin HS, Youn JH, Kim SH (2004) Hydrogen production from food waste in anaerobic mesophilic and thermophilic acidogenesis. Int J Hydrogen Energy 29:1355-1363

Shukla PR (1997) Energy for sustainable development: a social engineering perspective. Soc Eng 6:1-21

Singer JG (1981) Combustion: fossil power systems. Combustion Engineering Inc, Windsor

Tawarah KM (2014) Thermochemical assessment of solid and liquid fuels used for domestic space heating in Jordan. Green Sustain Chem 4:202-219

Tchobanoglous G, Theisen H, Vigil S (1993) Integrated solid waste management: engineering principles and management issues. McGraw-Hill, New York

Tomati U (2001) An European regulation about olive mill waste industry. In: Proceedings of 11th international symposium on environmental pollution and its impact in the Mediterranean region, Cyprus, C5, p 184, 6-10 Oct

Traore AS (1992) Biogas production from Calotropis procera: a latex plant fund in West Africa. Bioresour Technol 41:105-109

Ubay G, Ozturk I (1997) Anaerobic treatment of olive mill effluents. Water Sci Technol 36:287-294

Vitolo S, Petarca L, Bresci B (1999) Treatment of olive oil industry wastes. Bioresour Technol 67:29-37

World Nuclear Association (2010) Heat values of various fuels. Retrieved from the internet on March 2015 at http://www.worldnuclear.org/info/Facts-and-Figures/Heat-values-of-various-fuels/ 